\title{
Do Rising U.S. Interest Rates Imply A Stronger Dollar?
}

\author{
DOUGLAS R. MUDD
}

$\mathbf{R}$ ECENT U.S. monetary actions have been viewed, in part, as a reaction to the rapid depreciation of the U.S. dollar on foreign exchange markets over much of last year. Typical of this view is the statement: "The U.S. Federal Reserve . . confirmed its determination to push U.S. money market interest rates higher to support the dollar." 1 This view interprets rising U.S. interest rates as both an incentive for investors to purchase U.S. financial assets instead of foreign securities and a deterrent to U.S. residents' spending on goods and services, including imports.

Such an interpretation may be consistent with short-rum analysis. Over an extended period of time, however, rising U.S. interest rates are not necessarily accompanied by a rising foreign exchange value of the dollar. Moreover, this short-run view of the relationship between changes in U.S. interest rates and movements in the foreign exchange value of the dollar is not supported by a casual examination of recent data. For example, both long- and short-term U.S. interest rates rose, on average, relative to foreign interest rates from late 1977 to late 1978 . In addition, U.S. interest rates generally were higher than foreign interest

\footnotetext{
1Stewart Fleming and Peter Riddell, "Fed Confirms Aim to Raise Interest Rates in Aid of $\$$, Financial Times, July 24 , 1979. Also see Robert A. Bennett, "Fed Raises Rates to Aid Dollar," New York Times, July 21, 1979.
}

rates during this period. Yet, the weighted-average foreign exchange value of the dollar declined 17 percent between September 1977 and October 1978 (see Chart I). ${ }^{2}$

This article examines the relationship between changes in the U.S.-foreign interest rate differential and movements in the foreign exchange value of the dollar. The analysis is consistent with recent events and emphasizes the role of monetary disturbances in determining movements in both exchange rates and interest rates.

\section{Changes in Money Stock Growth and Interest Rate Movements}

The nation's money stock grows primarily through Federal Reserve purchases of government securities. To induce holders of securities to sell, the Federal Reserve offers them more than the currently prevailing market price for their securities. As a result, the price of government securities rises and the interest

2The countries included in the weighted-average foreign interest rate and exchange rate series are Belgium, Canada, France, Germany, Italy, Japan, the Netherlands, Sweden, Switzerland, and the United Kingdom. The weights and formula used in constructing these series are from "Index of the Weighted-Average Exchange Value of the U.S. Dollar: Revision, Federal Reserve Bulletin (August 1978), p. 700. 


\section{Chart I \\ Foreign Exchange Value of the U.S. Dollar and Interest Rate Differentials}

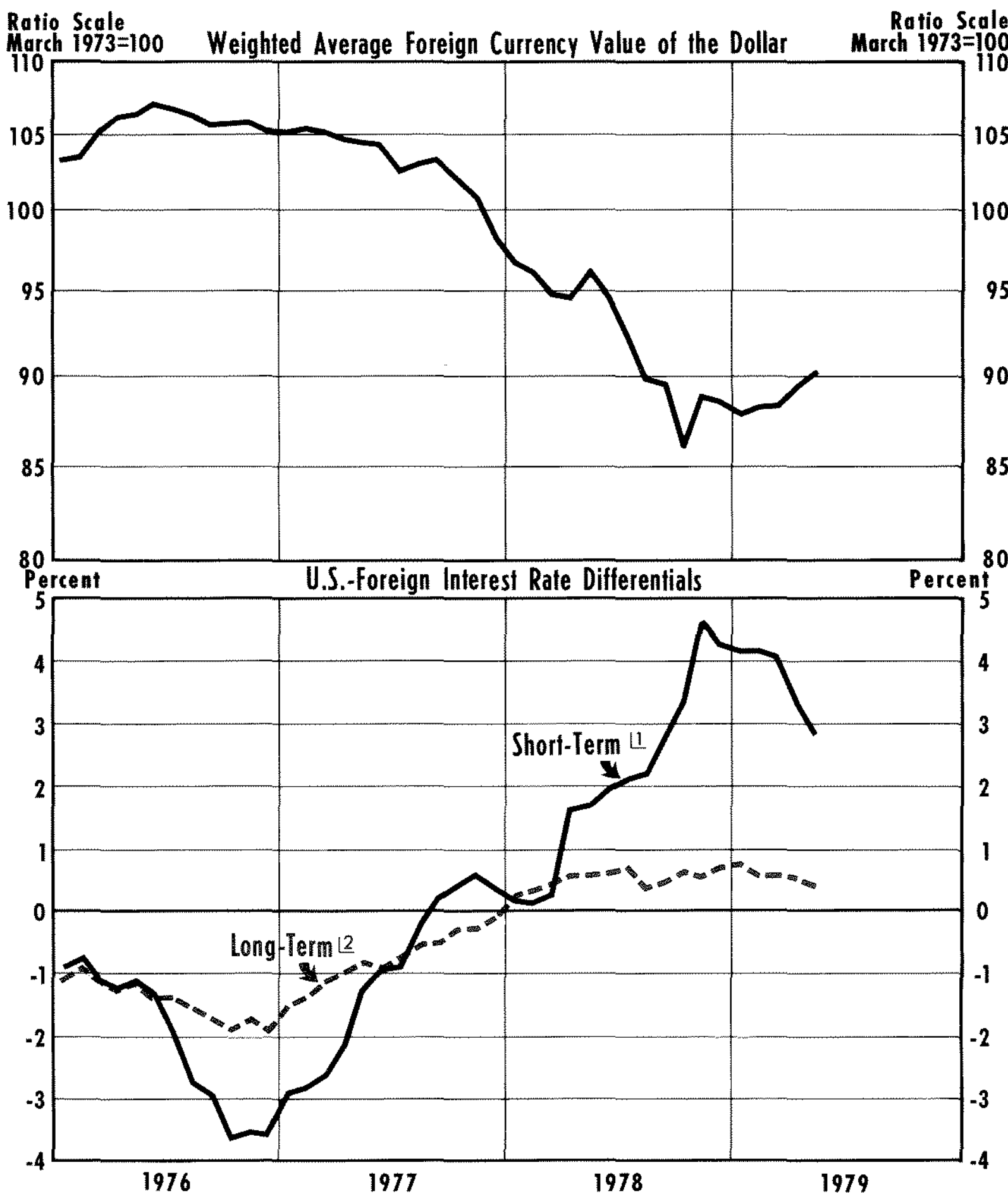

Sources: Federal Reserve Statistical Release H.13; Federal Reserve Bulletin; International Monetary

Fund, International Financial Statistics.

1 Secondary market rates for 90 -day large certificates of deposit in the United States less the weighted average of foreign three-month money markel rates.

12 U.S. long-term government bond yields less the weighted awerage of foreign long-ierm government bond yields.

Latest data plotted: May 
rate declines. Thus, an acceleration in money stock growth is associated, at least initially, with a decline in interest rates. Conversely, a deceleration in money stock growth initially is accompanied by a rise in interest rates.

An acceleration in money stock growth, however, is unlikely to produce permanently lower interest rates. One factor that would produce upward pressure on interest rates following an acceleration in money stock growth is an acceleration in the growth of aggregate spending. The acceleration in spending growth could be viewed as a direct result of the acceleration in money stock growth or as a result of the stimulation of consumption and investment spending by the initial decline in interest rates. In either case, an acceleration in spending would be accompanied by an acceleration in the growth of the quantity of credit demanded (to finance the accelerated pace of investment and consumption spending). If the rate at which the quantity of credit demanded grows more rapidly than the rate at which credit is being supplied, the price of credit (the interest rate on loans) rises.

The longer-term impact of faster money stock growth on the rate of inflation is another factor which would exert upward pressure on interest rates. Over longer periods of time, a sustained acceleration in the growth of aggregate spending will increase the rate of inflation (given that output growth is constrained in the long run by real factors which are unaffected by monetary disturbances).

It is generally accepted that movements in interest rates are, to some extent, influenced by changes in the expected rate of inflation. If ${ }^{3}$, for example, the interest rate is 6 percent and the price level is constant (that is, the inflation rate is zero), then the "real interest rate" would be 6 percent. Now, suppose inflation is widely expected to increase from zero to a 3 percent rate. Lenders would then require a 9 percent return on funds loaned (to prevent the real value of interest income and principal from falling) and borrowers would generally be willing to accept a 9 percent interest rate. ${ }^{4}$ Thus, factors that cause an increase in the expected rate of inflation also

\footnotetext{
${ }^{3}$ See Irving Fisher, The Theory of Interest (New York: Kelley \& Millman, Inc., 1954), pp. 36-44.

tThis example is oversinplified in several respects. However, the basic point that an increased value of the expected rate of inflation raises nominal interest rates remains valid. For a concise theoretical discussion, see Robert Mundel, "Inflation and Real Interest," Journal of Political Economy (June 1963), pp. 280-83.
}

produce upward pressure on interest rates. One such factor is a sustained acceleration in money stock growth.

Within the context of this discussion, an acceleration in money stock growth initially will be associated with a decline in interest rates. If, in the long. rum, however, the real interest rate is unaffected by monetary disturbances and the acceleration of money stock growth is sustained, interest rates ultimately will rise. In other words, changes in money stock growth initially are related inversely to changes in interest rates, but, in the long-run, money stock growth, the inflation rate, and interest rates all move in the same direction.

\section{Changes in Money Stock Growth and Exchange Rate Movements}

When a currency is traded in foreign exchange markets, the exchange rates which evolve are the prices of that currency in terms of each of the other currencies traded. Thus, relative changes in the total amounts of these national moneys supplied and demanded will determine exchange rate movements. Only if the amounts of all national moneys demanded increase at the same rate would relative changes in money stock growth rates alone determine exchange rate movements.

For example, suppose that growth in both the U.S. and German money stocks equal the rates at which the amounts of these national moneys demanded increase. Assume that interest rates in both countries are equal and that neither central government intervenes in the foreign exchange market. Now let U.S. money stock growth accelerate. As previously discussed, this acceleration, at first, will be accompanied by a decline in U.S. interest rates. Initially, given interest rates in Germany, U.S. capital outflows will be encouraged (that is, the rate at which U.S. residents invest in German securities will rise) and German capital outflows would be discouraged (the rate at which German residents invest in U.S. securities will fall). This results in an increase in the amount of dollars supplied in the foreign exchange market (by U.S. residents wishing

\footnotetext{
5For a more technical theoretical discussion of this relationship, see Milton Friedman, "Factors Affecting the Level of Interest Rates," in John T. Booman and Thomas M. Havtilesky, Money Stuply, Money Demand, and Macroeconomic Models (Northbrook, Ill: AHM Publishing Corporation, 1972), pp. 200-18. For empinical support of this view, see William E. Gibson, "Interest Rates and Monetary Policy," Journal of Political Economy (May/June 1970), pp. 431-55.
} 
to purchase marks to invest in German securities) relative to the amount of dollars demanded (by German residents desiring dollars to spend in the United States). Therefore, the U.S. dollar price of one German mark will be subject to upward pressure the dollar will fall in value on the foreign exchange market.

The stimulative effect of the U.S. monetary expansion on the growth of U.S. income and spending will also contribute to this downward pressure on the value of the dollar. In other words, the rate at which U.S. residents purchase both domestic and German goods and services will rise. This acceleration in U.S. import growth will also contribute to the acceleration in the rate at which dollars are supplied on foreign exchange markets. ${ }^{6}$

If the faster pace of U.S. money stock growth continues, the U.S. inflation rate will eventually rise. Thus, the faster U.S. money stock growth will tend to increase the expected future rate of U.S. inflation. This, in turn, will cause U.S. interest rates to rise relative to German interest rates. The increase in the U.S.-German interest rate differential, however, will not necessarily produce capital flows from Germany into the United States. Instead, the foreign exchange value of the dollar might depreciate at the same time that U.S. interest rates are higher than, and rise relative to, German interest rates.

\section{Interest Rate Differentials and \\ Exchange Rate Movements}

The preceding analysis indicates that U.S. interest rates could be both higher than, and rise relative to, foreign interest rates without providing an incentive for foreign investors to increase their purchases of U.S. securities (or U.S. investors to decrease their purchases of foreign securities). The reason for this is that the difference between U.S. and foreign interest rates is, in fact, not the relevant factor in inducing capital flows. Rather, the interest rate differential adjusted for expected future exchange rates is the relevant factor inducing international capital flows.

Exchange rate expectations, interest rate differentials, and exchange rates will, in the absence of

the acceleration in U.S. import growth would accelerate income growth in the German export sector. However, from a monetarist viewpoint, German aggregate income growth would remain constant since German money stock growth is constant. This implies a deceleration in income growth in other sectors of the German economy. controls on international capital flows, be related according to the equilibrium condition,

$$
\left(1+r_{u s}\right)=\frac{1}{x} \cdot\left(1+r_{f}\right) x^{*},
$$

where,

$$
\begin{aligned}
& \mathbf{r}_{\mathrm{us}}=\text { the U.S. interest rate } \\
& \mathbf{r}_{\mathrm{f}}=\text { the foreign interest rate } \\
& \mathrm{x}=\text { the spot (currently prevailing) U.S. dollar/foreign } \\
& \text { cutrency exchange rate } \\
& \mathrm{x}^{*}=\text { the expected future value of the U.S. dollar/foreign } \\
& \text { currency exchange rate. }
\end{aligned}
$$

Consider the following example. Suppose the spot U.S. dollar/German mark exchange rate is $\$ .33 / \mathrm{DM}$ and that the value of the dollar in terms of the mark is expected to decline to $\$ .36 / \mathrm{DM}$ during the next year (an expected depreciation of 9 percent). Suppose the interest rate on one-year German Treasury bills was 5 percent, so that $\$ 1.00$ could be used to purchase 3.03 marks which would yield 3.18 marks (DM3.03 $\cdot(1+.05)$ ) after one year. When the marks are converted back to dollars, U.S. investors expect to receive \$1.14 (DM3.18 * $(\$ .36 / \mathrm{DM}))$. If U.S. investors could earn $\$ 1.14$ on a $\$ 1.00$ investment in U.S. Treasury bills, the U.S. interest rate would be 14 percent and no capital flows would occur. Thus, in equilibrium, the differential between U.S. and foreign interest rates equals the expected dollar-denominated return on investments in foreign securities. ${ }^{7}$ This can be expressed

$$
r_{u s}-r_{t}=\left(\frac{x^{e}}{x}-1\right) \cdot\left(1+r_{t}\right),
$$

where $\left(\frac{x^{e}}{x}-1\right)$ is the expected change in the foreign exchange value of the dollar:

If U.S. interest rates rise relative to foreign interest rates and equation (2) holds, the foreign exchange value of the dollar could decline (that is, $x$ could rise), but the expected future foreign exchange value of the dollar could decline even faster ( $x^{e}$ could rise faster). In other words, for given levels of foreign interest rates, a rising U.S. interest rate could be offset by progressively larger declines in the expected foreign exchange value of the dollar.

\footnotetext{
7 Although this relationship does not hold exactly, the differences between the interest rate differential and the forward preminm or discomt (the expected change in the exchange rate) may reflect the existence of transactions costs and political risk (for example, the likelihood that a conntry will inpose exchange controls). See Jacob A. Frenkel and Richard M. Levich, "Covered Interest Arbitrage: Unexploited Profits?" Journal of Political Economy (April 1975), pp. 325-38 and Robert Z. Aliber, "The Interest Rate Parity Theorem; A Reinterpretation," Journal of Political Economy (November/
} December 1973), pp. 1451-59. 
One explanation for the occurrence of this situation is that monetary disturbances dominate both changes in interest rates and exchange rates. As previously discussed, a sustained acceleration in U.S. money stock growth will ultimately result in an increase in the expected rate of inflation. This, in turn, produces an increase in U.S. interest rates. Given the expected foreign rate of inflation, the differential between U.S. and foreign interest rates will be rising. Simultaneously, the faster rate of U.S. spending growth would produce a declining foreign exchange value of the dollar. In addition, if U.S. money stock growth and inflation are expected to continue at the faster pace, the expected future value of the dollar on foreign exchange markets will tend to decline faster. ${ }^{8}$

\section{Summary}

The assertion that rising U.S. interest rates (relative to foreign rates) produce an increase in the foreign exchange value of the dollar has not been supported by recent experience. If monetary disturbances are important determinants of changes in both interest rates and exchange rates, a widening positive differential between U.S. and foreign interest rates and a declining foreign exchange value of the dollar are consistent developments. If the expected rate of U.S. inflation increases because of a sustained acceleration in U.S. money stock growth

\footnotetext{
SThese results have been derived by assuming that current accelerations in U.S. money stock growth and inflation are important variables in the formulation of increases in the expected rate of inflation which, in tum, is important in determining changes in the expected foreign exchange value of the dollar.
}

(while foreign expected rates of inflation remain relatively stable), U.S. interest rates will rise relative to foreign interest rates. The faster pace of U.S. money stock growth also will produce an increase in U.S. spending growth, which, in turn, will result in a depreciating foreign exchange value of the dollar. If the higher expected rate of U.S. inflation also results in an offsetting decline in the expected value of the dollar on foreign exchange markets, no capital inflow will be induced by the rising differential between U.S. and foreign interest rates.

Conversely, a sharp deceleration in U.S. money stock growth (not matched by equally restrictive foreign monetary developments) will produce an appreciation of the dollar. In this case, initially U.S. interest rates will rise relative to foreign rates and U.S. spending growth will slow. As a result, the supply of dollars on foreign exchange markets will fall (as U.S. residents reduce spending for foreign goods, services, and securities) relative to the demand for dollars (as foreign investors increase purchases of U.S. securities in response to the higher U.S. interest rate). However, if the slower U.S. money stock growth is sustained and the expected rate of U.S. inflation is revised downward, U.S. interest rates will decline relative to foreign rates. Further, if the restrictive U.S. monetary actions also produce large upward revisions in the expected future value of the dollar, no capital outflow will result from the declining U.S.-foreign interest rate differential. In this case, an appreciation of the dollar on foreign exchange markets will initially be associated with a rising U.S.-foreign interest rate differential. Eventually, however, the interest rate differential will decline while the dollar continues to appreciate.

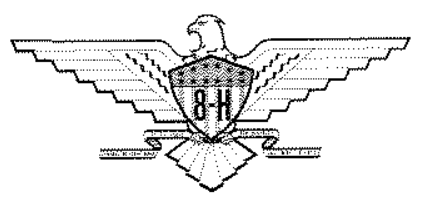

